\title{
Human Discharge and Phytoplankton Takeup for the Atmospheric Carbon Balance*
}

\author{
Dongfang Yang ${ }^{1,2,3}$, Zhenqing Miao ${ }^{1}$ Yu $\mathrm{Chen}^{2}$, Qiang Shi ${ }^{3}$, Huanzhi Xu ${ }^{1}$ \\ ${ }^{1}$ Marine Science College, Zhejiang Ocean University, Zhoushan, China \\ ${ }^{2}$ Information College, Shanghai Ocean University, Shanghai, Shanghai, China \\ ${ }^{3}$ North China Sea Environmental Monitoring Center, SOA, Qingdao, China \\ E-mail: dfyang@shou.edu.cn \\ Received July 19, 2011; revised August 25, 2011; accepted September 11, 2011
}

\begin{abstract}
By the data of the Jiaozhou Bay (Shandong, China) from May 1991 to February 1994 and those of Hawaii from March 1958 to December 2007, with the statistics and differential equations analyzed were the seasonal variations in atmospheric carbon in the Northern Pacific Ocean (NPO), and in phytoplankton primary production in the Jiaozhou Bay, and its relationship in the study regions. The study unveiled that the seasonal change of the atmosphere carbon and primary production has the same period. In a year, the primary production and atmosphere carbon had two balance points: the points of May and October, during which the amount of atmosphere carbon decreased. As phytoplankton absorbed atmosphere carbon, When primary production in spring $>181.60$ $\left(\mathrm{mg} / \mathrm{m}^{2} \mathrm{~d}\right)-297.57\left(\mathrm{mg} / \mathrm{m}^{2} \mathrm{~d}\right)$ or $754.74\left(\mathrm{mg} / \mathrm{m}^{2} \mathrm{~d}\right)-1160.13\left(\mathrm{mg} / \mathrm{m}^{2} \mathrm{~d}\right)$ in September or $552.94\left(\mathrm{mg} / \mathrm{m}^{2} \mathrm{~d}\right)$ $890.69\left(\mathrm{mg} / \mathrm{m}^{2} \mathrm{~d}\right)$ in October, the atmosphere carbon fell. Therefore, it is considered that from May to October every year, phytoplankton growing in bloom controlled the increase of atmosphere carbon. From December to next April, human discharging the carbon controlled its increase. The results supported the viewpoint shown by Yang (2010): the variation in atmospheric carbon was determined by human discharge and phytoplankton growth. The result in this paper showed that the earth ecosystem kept the percentage of the decrease amount of atmospheric carbon to its amount taken up by phytoplankton as $1.60 \%-0.34 \%$ and maintained the dynamic balance of carbon by emitted by human being into the atmosphere and absorption of phytoplankton to atmosphere carbon. Therefore, the ecosystem was considered to be of the great power and accuracy.
\end{abstract}

Keywords: Atmospheric Carbon, Human, Phytoplankton, Dynamic Balance, Jiaozhou Bay, Hawaii

\section{Introduction}

Since industry revolution, the atmosphere carbon concentration rises obviously every year, which leads to global warming and affects the climate and environment of the earth. $95 \%$ of the carbon in ecological circle lies in ocean, which is the largest carbon store of the earth. It contains the $\mathrm{CO}_{2}$ not only from atmosphere but also from mankind within river water, that is, the recycling mechanism and the physical, chemical and biological process, where oceans absorb and transfer $\mathrm{CO}_{2}$ in atmosphere and ocean will change with season, area and space. Therefore, ocean is of great meaning to adjust the $\mathrm{CO}_{2}$ in atmos-

\footnotetext{
*Funded by Key Laboratory of Marine Spill Oil Identification and Damage Assessment Technology, SOA, the Director's Foundation of the Beihai Monitoring Center, the State Oceanic Administration; and a Project of Chinese Academy of Science (KZCX 2-207).
}

phere.

In central area of the North Pacific, Hawaii Mauna Loa Monitoring Station found that atmosphere carbon is not affected by partial carbon emission and the data of the carbon reflects the change of atmosphere carbon in north Pacific. Along the coast line of the north Pacific, the Jiaozhou bay with suitable location [1-9] is chosen to observe the effect of phytoplankton growth on atmosphere carbon. The data from Mauna Loa Monitoring Station were valid and reliable, which were used by many researchers [10-13].

This paper showed the seasonal change of phytoplankton primary production in the Jiaozhou Bay from 1992 to 1994, that of atmospheric carbon from 1958 to 2007 in Mauna Loa in NOAA Earth System Research laboratory in Hawaii that of the atmosphere in the North Pacific ocean. By the equations, calculated were monthly 
average value of primary production, their balance points and balance amounts, making us fully understand the phytoplankton growth role in atmospheric carbon elimination.

\section{Materials and Method}

\subsection{The Jiaozhou Bay and the Phytoplankton Data}

Jiaozhou Bay is semi-closed at $35^{\circ} 55^{\prime} \mathrm{N}-36^{\circ} 18^{\prime} \mathrm{N}, 120^{\circ}$ $04^{\prime} \mathrm{E}-120^{\circ} 23^{\prime} \mathrm{E}$, its area is $390 \mathrm{~km}^{2}$ with $7 \mathrm{~m}$ in average depth in the eastern China. The observation data of primary production (14C-monitoring) from May 1991 to February 1994 are provided by the Ecological Station of Jiaozhou Bay, and obtained by Wu et al. [14]. Each time monitoring was taken in 2 days. On-site the investigations were made in February, May, August, and November during the years, representing winter, spring, summer, and autumn, respectively. There were 12 voyages in 10 stations (except Station 3) (Figure 1). The water Samples of standard water layer were collected at $0,5,10, \ldots$, to the bottom).

\subsection{Mauna Loa and Source of Atmospheric Carbon Data in Hawaii}

Mauna Loa is located at $19.539 \mathrm{~N} / 155.578 \mathrm{~W}$ in Hawaii (Figure 2), its altitude is $4170 \mathrm{~m}$ high and its area is 97 $\mathrm{km}$ in length and $48 \mathrm{~km}$ in width. The observation data on atmospheric carbon in 1958-2007 are from Mauna Loa in NOAA Earth System Research laboratory in Hawaii.

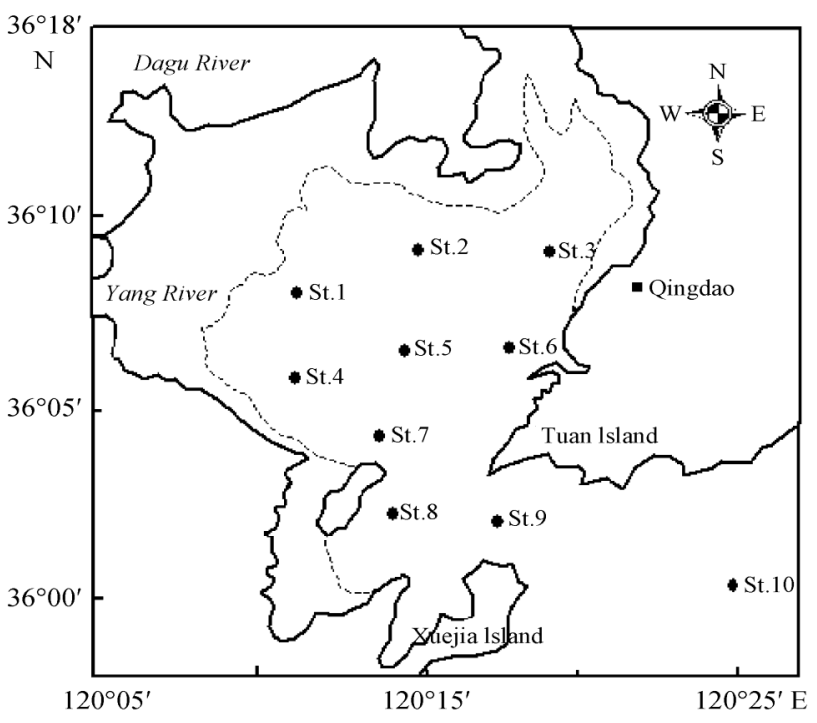

Figure 1. Station locations in Jiaozhou Bay.
The change of atmosphere carbon is a curve of fluctuating rise. This change is produced by the combination of trending increase and periodic fluctuation [9]. The thesis researches the change of curve period and makes comparison analysis according to the curve period change calculated by monthly average value to discuss the effect of primary productivity to seasonal change of atmosphere carbon.

Variation in atmospheric carbon shows cycle oscillation in curved shape, resulted jointly from the increasing trend and periodic oscillations [9]. The seasonal variations in atmospheric carbon and primary production were compared and analyzed by the calculated monthly average (Figures 3-4), by which their balance points and balance amounts were obtained.

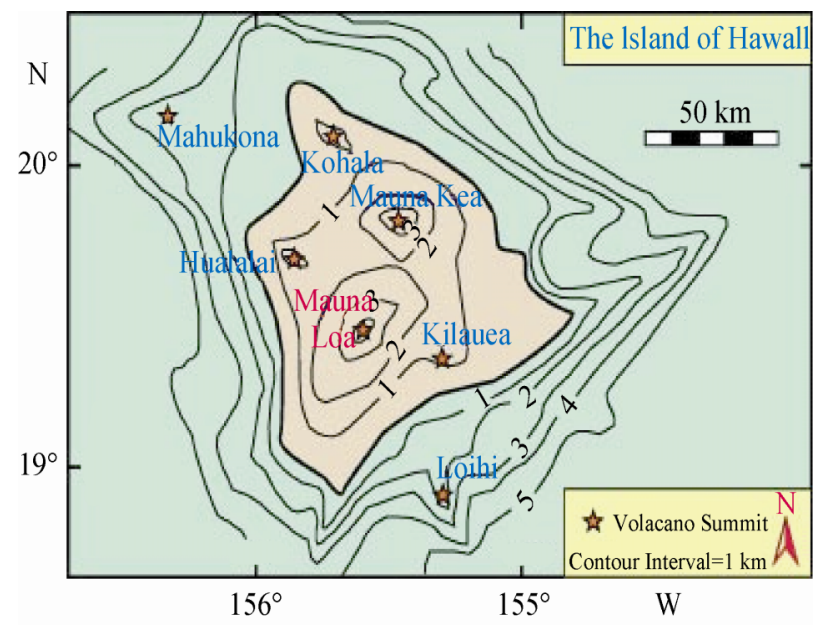

Figure 2. Geographic feature of Mauna Loa monitoring station (from NOAA Earth System Research Laboratory, http://www.esrl.noaa.gov/gmd/ccgg/trends/co 2 data_mlo.ht $\mathrm{ml}$, seen on the 20th February in 2008).

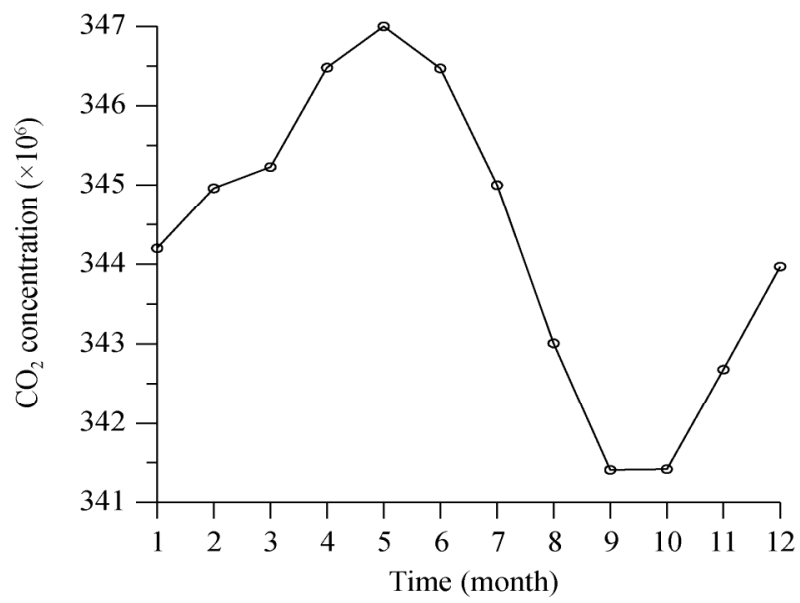

Figure 3. The variation in atmospheric carbon with a monthly average from March 1958 to December 2007. 


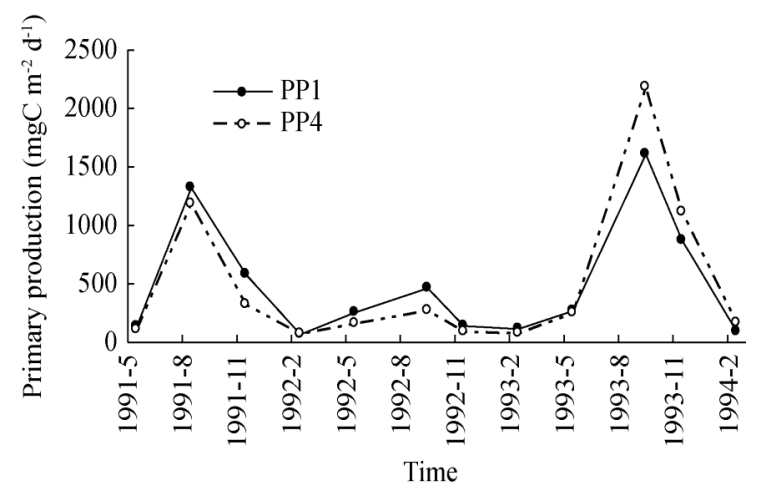

Figure 4. Seasonal variations of primary production at Stations 1 and 4 (mgCm-2d-1).

\section{Results}

\subsection{Seasonal Variation in Atmospheric Carbon}

According to the monthly average value of atmospheric carbon concentration from 1958 to 2007, the seasonal variation in it reaches the peak in spring, higher than in other three seasons, while it arrives to the bottom in autumn. The average atmospheric carbon from November to next May all the times rises, and reaches the highest value $347 \mathrm{ppm}$ in May in a year, and then begins to go down in May and falls all the time from May to October for five months. In August it falls faster, then in September it falls slowly and reaches the lowest value $341.41 \mathrm{ppm}$ in September, then kept the lowest value $341.42 \mathrm{ppm}$ in October. Moreover, it begins to rise in November and reaches again the peak until the next May for seven months, in April, it rises faster and reaches the peak of $347^{\circ} \mathrm{ppm}$ in May again. Then, a new cycle appeared again (Figure 3).

\subsection{Seasonal Variation in Primary Production}

In Jiaozhou bay, the seasonal change tendency of primary production is obvious. The primary production is the highest in summer. In the same station, the primary production peak value of every year is different. The peak value in the same station is not the same in different years. The peak value is in the range of $1600 \mathrm{mgC} / \mathrm{m}^{2} \mathrm{~d}$ $2500 \mathrm{mgC} / \mathrm{m}^{2} \mathrm{~d}$. The bottom value of primary production is in winter with the range of $35 \mathrm{mgC} / \mathrm{m}^{2} \mathrm{~d}-104 \mathrm{mg}$ $\mathrm{C} / \mathrm{m}^{2}$ d. Primary production from February to May rises slowly and rises fast after May till peak period. It will then fall sharply till November and then falls slowly from November to February and slides to bottom value. The primary production remains low from November to the next May. Then the cycle continues, such as Stations 1 and 4 (Figure 4).

Primary production and atmospheric carbon have the clear seasonal variation and the same cycle.

\subsection{Monthly Average Value of Primary Production}

By the primary production data of May, August and November in 91, 92, 93, approximate formula is set up with parabola formula least squares. The variable is time $t$ with the unit of month. The month is 30 days and function is primary production (Table 1).

$$
\mathrm{Y}(\mathrm{t})=\mathrm{at} 2+\mathrm{bt}+\mathrm{c}
$$

Function $Y(t)$ was obtained by carrying out integral to primary production function $\mathrm{Y}(\mathrm{t})$ and the average value of primary production for every month was calculated. $\mathrm{Y}(\mathrm{t})=\int \mathrm{y}(\mathrm{t}) \mathrm{dt}(2)$.

From (2), the primary production average value of May, September and October can be worked out (Table 2).

Table 1. Values of the parameters a, b, $c$ in Equation (1).

\begin{tabular}{|c|c|c|c|c|c|c|}
\hline $\mathrm{P}$ & 1 & 4 & 6 & 7 & 8 & 9 \\
\hline $\mathrm{a}$ & -85.04 & -99.07 & -69.87 & -61.00 & -114.04 & -85.65 \\
\hline $\mathrm{b}$ & 1479.81 & 1724.32 & 1192.24 & 1045.63 & 1926.34 & 1465.68 \\
\hline $\mathrm{c}$ & -5306.05 & -6283.54 & -4256.25 & -3667.57 & -6837.91 & -5239.47 \\
\hline $\mathrm{r} 2$ & 0.54 & 0.41 & 0.51 & 0.49 & 0.54 & 0.24 \\
\hline
\end{tabular}

S: Station, P: Parameter.

Table 2. Month average values of the primary production $\left(\mathrm{mg} / \mathrm{m}^{2} \mathrm{~d}\right)$.

\begin{tabular}{|c|c|c|c|c|c|c|}
\hline$M^{S}$ & 1 & 4 & 6 & 7 & 8 & 9 \\
\hline May & 253.24 & 194.99 & 181.60 & 232.79 & 297.57 & 223.65 \\
\hline Sep. & 1069.86 & 1147.84 & 758.16 & 754.74 & 1160.13 & 947.19 \\
\hline Oct. & 848.79 & 890.69 & 552.94 & 580.18 & 805.54 & 699.81 \\
\hline
\end{tabular}

S: Station, M: Month. 
The monthly average value of primary production in May was in the range of $181.60\left(\mathrm{mg} / \mathrm{m}^{2} \mathrm{~d}\right)-297.57$ $\left(\mathrm{mg} / \mathrm{m}^{2} \mathrm{~d}\right)$, in September in the range of $754.74\left(\mathrm{mg} / \mathrm{m}^{2} \mathrm{~d}\right)$ - $1160.13\left(\mathrm{mg} / \mathrm{m}^{2}\right)$, and in October in the range of 552.94 $\left(\mathrm{mg} / \mathrm{m}^{2} \mathrm{~d}\right)-890.69\left(\mathrm{mg} / \mathrm{m}^{2} \mathrm{~d}\right)$.

\subsection{The Balance Point of Primary Production and Atmosphere Carbon}

The atmosphere carbon increases before May and decreases after May. In May, the atmosphere carbon reaches the peak value of $347 \mathrm{ppm}$. At the same time, primary production increases from February to August, during which primary production decreases atmosphere carbon. In May, atmosphere carbon and primary production reaches the balance, that is, the absorption amount of phytoplankton for atmosphere carbon is equal to the increase amount of atmosphere carbon. This result shows that in spring, the primary production rises, and that its month average value exceeds $181.60\left(\mathrm{mg} / \mathrm{m}^{2} \mathrm{~d}\right)-297.57$ $\left(\mathrm{mg} / \mathrm{m}^{2} \mathrm{~d}\right)$, atmospheric carbon begins to fall.

Atmosphere carbon decreases before September and October, and increases after September and October. In September and October, atmosphere carbon reaches the lowest values $341.41 \mathrm{ppm}$ and $341.42 \mathrm{ppm}$, and then primary production falls to the bottom value from August to next February, during which, primary production makes the atmospheric carbon decreasing, but as primary

Production falls, the atmospheric carbon correspondingly increases. So, In September and October, atmospheric carbon and primary production reaches the balance, that is, the absorption amount of phytoplankton for atmosphere carbon is equal to the increase amount of atmosphere carbon. This result shows that in autumn, the primary production falls, and that its month average value reaches lower than $754.74\left(\mathrm{mg} / \mathrm{m}^{2} \mathrm{~d}\right)-1160.13\left(\mathrm{mg} / \mathrm{m}^{2} \mathrm{~d}\right)$ in September or $552.94\left(\mathrm{mg} / \mathrm{m}^{2} \mathrm{~d}\right)-890.69\left(\mathrm{mg} / \mathrm{m}^{2} \mathrm{~d}\right)$ in October, atmospheric carbon begins to rise.

\subsection{The Balance Amount of Primary Production and Atmosphere Carbon}

Primary production and atmosphere carbon have two balance points. The accumulation amount between them is called balance amount of primary production and atmosphere carbon. So, the accumulation amount of primary production is defined the balance amount of atmospheric carbon between primary production and atmosphere carbon by authors, in this way the accumulation amount of atmospheric carbon is called the balance amount of atmospheric carbon between primary production and atmosphere carbon.

From Formula 2 obtained was the average value of primary production $600.18-931.71\left(\mathrm{mg} / \mathrm{m}^{2} \mathrm{~d}\right)$ from May to October.

There is six months in all from May to October; every month is 30 days, namely 180 days. Then there the accumulation amount of primary production for six months, that is, the balance amount of primary production between primary production and atmosphere carbon for six months (Table 3), its range is $108031.95-167707.62\left(\mathrm{mg} / \mathrm{m}^{2}\right)$.

By calculating the data of primary production in the Jiaozhou Bay and atmospheric carbon in Hawaii, set up was the Equation (3): $\mathrm{c}(\mathrm{t})=-\mathrm{kp}(\mathrm{t})+\mathrm{b}$

In (3), parameter $\mathrm{k}$ is the amount of atmospheric carbon absorbed by unit primary production as 0.00321 (ppm) $/\left(\mathrm{mgC} \mathrm{m}{ }^{-2} \cdot \mathrm{d}^{-1}\right)$ - $0.00974(\mathrm{ppm}) /\left(\mathrm{mgC} \mathrm{m} \mathrm{m}^{-2} \cdot \mathrm{d}^{-1}\right)$, that is, a unit primary production can absorb $0.003^{\circ} 21$ ppm - 0.00974 ppm of the atmospheric carbon (Yang, et al., 2010). With (3) the atmospheric carbon average from May to October is calculated, the range of low value is $1.93 \mathrm{ppm}-2.99 \mathrm{ppm}$ and that of high value is $5.85 \mathrm{ppm}$ $9.07 \mathrm{ppm}$. The whole range is $1.93 \mathrm{ppm}-9.07 \mathrm{ppm}$. There is six months in all from May to October; every month is 30 days, namely 180 days. Then there the accumulation amount of atmospheric carbon for six months, that is, the balance amount of atmospheric carbon between primary production and atmosphere carbon for six months (Table 4), its low range is $346.78 \mathrm{ppm}-538.34$ ppm; its high range1052.23 ppm - $1633.47 \mathrm{ppm}$; The whole range is $346.78 \mathrm{ppm}-1633.47 \mathrm{ppm}$.

Table 3. Average value $\left(\mathrm{mg} / \mathrm{m}^{2} \mathrm{~d}\right)$ and balance amount $\left(\mathrm{mg} / \mathrm{m}^{2}\right)$ of the primary production between the primary production and the atmospheric carbon for six months.

\begin{tabular}{ccccccc}
\hline Primary production & PP1 & PP4 & PP6 & PP7 & PP8 & \\
\hline Average value of six months & 834.50 & 873.09 & 600.18 & 609.85 & 931.71 & 747.24 \\
Balance amount & & & & & & \\
& 150209.17 & 157155.71 & 108031.95 & 109773.85 & 167707.62 & 134503.24 \\
\hline
\end{tabular}


Table 4. Average value and balance amount of the atmospheric carbon between the primary production and the atmospheric carbon for six months (ppm).

\begin{tabular}{|c|c|c|c|c|c|c|c|}
\hline $\begin{array}{l}\text { Atmosphere carbon amount ab- } \\
\text { sorbed by primary production unit }\end{array}$ & Atmosphere carbon & 1 & 4 & 6 & 7 & 8 & 9 \\
\hline $0.00321(\mathrm{ppm}) /\left(\mathrm{mgC} \mathrm{m}^{-2} \cdot \mathrm{d}^{-1}\right)$ & Average value of 6 months & 2.68 & 2.80 & 1.93 & 1.96 & 2.99 & 2.40 \\
\hline $0.00974(\mathrm{ppm}) /\left(\mathrm{mgC} \mathrm{m}^{-2} \cdot \mathrm{d}^{-1}\right)$ & Average value of 6 months & 8.13 & 8.50 & 5.85 & 5.94 & 9.07 & 7.28 \\
\hline $0.00321(\mathrm{ppm}) /\left(\mathrm{mgC} \mathrm{m}^{-2} \cdot \mathrm{d}^{-1}\right)$ & Balance amount & 482.17 & 504.47 & 346.78 & 352.37 & 538.34 & 431.76 \\
\hline $0.00974(\mathrm{ppm}) /\left(\mathrm{mgC} \mathrm{m}^{-2} \cdot \mathrm{d}^{-1}\right)$ & Balance amount & 1463.04 & 1530.70 & 1052.23 & 1069.20 & 1633.47 & 1310.06 \\
\hline
\end{tabular}

\section{Discussion}

\subsection{Rise of $\mathrm{CO}_{2}$ in Atmosphere}

Human beings by burning oil emitted a huge amount of $\mathrm{CO}_{2}$ into the atmosphere, so $\mathrm{CO}_{2}$ concentration has been rising from $270 \mathrm{ppm}$ of the industrial revolution to $315.24 \mathrm{ppm}$ in $1958,318.46 \mathrm{ppm}$ in 1962 after 5 years, $322.18 \mathrm{ppm}$ in 1967 after 10 years, and $383.71 \mathrm{ppm}$ in 2007 after 50 years [9]. Therefore, because of human beings, the $\mathrm{CO}_{2}$ in the atmosphere increases faster and faster. During the period of 1958-2007, by virtue of monthly average value, the equation of atmosphere carbon curve was set up [9], by which it can be calculated that the acceleration of atmospheric $\mathrm{CO}_{2}$ is 0.0244 since 1958 , and in the future, the its increasing speed would look faster. Therefore, the rise of $\mathrm{CO}_{2}$ in the atmosphere is faster and faster.

\subsection{Absorption of Primary Production for Atmosphere Carbon}

Oceans are the largest absorbing body of $\mathrm{CO}_{2}$ as $\mathrm{CO}_{2}$ can be solved in sea water; a large amount of atmosphere carbon is in sea water. Phytoplankton absorbs carbon and settles it at the bottom of ocean. The phytoplankton in the ocean transfers the carbon into the sea bottom [15-18]. One of two functions of phytoplankton growth is the basis of food chain and the core of ecosystem, the other one is the elimination of the atmospheric $\mathrm{CO}_{2}$ by phytoplankton photosynthesis. Therefore, phytoplankton growth would keep the ocean ecosystem to sustain and decrease the atmospheric $\mathrm{CO}_{2}$ emitted by the humans [9].

Atmospheric carbon has a close relationship with phytoplankton primary production. Jiaozhou Bay phytoplankton is relevant to Hawaii atmosphere carbon. A good correlation between phytoplankton in Jiaozhou Bay and atmospheric carbon in Hawaii showed the process of phytoplankton taking up carbon from atmosphere and sinking to the ocean bottom.
The carbon-phytoplankton model $[9,16]$ showed that if the primary production rises, the atmospheric carbon will fall; if the primary production falling, the result on the contrary. In addition, under the effect of phytoplankton, atmospheric carbon has the same period of phytoplankton, which means the phytoplankton growth determined the cyclic fluctuation and the amplitude of atmosphere carbon.

From the carbon-phytoplankton model $[9,16], 0.00321$ $0.00974 \mathrm{ppm}$ of the atmospheric carbon is absorbed by every primary production unit. In the way, $0.28963 \mathrm{ppm}$ - $0.87884 \mathrm{ppm}$ of the atmospheric carbon is absorbed in winter, $6.88689 \mathrm{ppm}-20.89668 \mathrm{ppm}$ in summer, which unveiled that the amount of atmospheric carbon is very different in the absorption of phytoplankton between winter and summer. Therefore, phytoplankton growth in bloom and decline determines the fall and rise variation in atmospheric carbon.

\subsection{Balance Point of May}

The atmosphere carbon increases from February to May continuously, then primary production increases from February to August continuously. During this period, the increase amount of primary production becomes large, the corresponding increase amount of atmospheric carbon becomes smaller. In this way, primary production increased fast and the corresponding atmospheric carbon increased slowly. So, in May, the balance of atmosphere carbon and primary production appears, that is, the absorption amount of phytoplankton for atmosphere carbon and the increase amount of atmosphere carbon reaches the balance, and then the atmosphere carbon reaches the peak value of $347 \mathrm{ppm}$. This result indicated that in spring, the primary production rises, and that when the monthly average value of primary production exceeds $181.60\left(\mathrm{mg} / \mathrm{m}^{2} \mathrm{~d}\right)-297.57\left(\mathrm{mg} / \mathrm{m}^{2} \mathrm{~d}\right)$, atmospheric carbon begins to decrease. Therefore, the bloom of phytoplankton growth might control the rise of atmospheric carbon. 
The largest increase rate of primary production is in May [1-3,19], That is, it is time that the phytoplankton begins to grow in bloom, the absorption amount of phytoplankton for atmosphere carbon and the increase amount of atmosphere carbon is identical, resulting in rise of atmosphere carbon as zero.

\subsection{Balance Point of October}

Atmosphere carbon decreases all along from May to September and October, then atmospheric carbon increases all along, but decreases from August to November, during this period the increase amount of primary production becomes smaller, the corresponding increase amount becomes larger. In this way, since August, the primary production rises slowly, the corresponding atmospheric carbon rises fast. So in September and October the second balance point appears, that is, the absorption amount of phytoplankton for atmosphere carbon and the increase amount of atmosphere carbon reaches the balance in September and October, and then the atmosphere carbon reaches separately the bottom values of $341.41 \mathrm{ppm}$ and $341.42 \mathrm{ppm}$ in September and October. This result indicated that in autumn, the primary production falls, and that when the monthly average value of primary production is lower than $754.74\left(\mathrm{mg} / \mathrm{m}^{2} \mathrm{~d}\right)$ $1160.13\left(\mathrm{mg} / \mathrm{m}^{2} \mathrm{~d}\right)$ in September or $552.94\left(\mathrm{mg} / \mathrm{m}^{2} \mathrm{~d}\right)$ $890.69\left(\mathrm{mg} / \mathrm{m}^{2} \mathrm{~d}\right)$ in October, atmospheric carbon begins to rise. Therefore, the decline of phytoplankton growth might not control the rise of atmospheric carbon.

The largest decrease rate of primary production is in November $[1-3,19]$, That is, it is before that the phytoplankton begins to grow in weak, the absorption amount of phytoplankton for atmosphere carbon and the increase amount of atmosphere carbon is identical, resulting in rise of atmosphere carbon as zero.

Therefore, in one year, from May to October, phytoplankton growth all along controls the rise of atmospheric carbon.

\subsection{Average Value of Primary Production and Atmospheric Carbon}

From May to October, the average primary production is $600.18\left(\mathrm{mg} / \mathrm{m}^{2} \mathrm{~d}\right)-931.71\left(\mathrm{mg} / \mathrm{m}^{2} \mathrm{~d}\right)$ and the primary production growth controls the rise of atmosphere carbon. During this period, the atmospheric carbon amount absorbed by the primary production has the low range of $1.93 \mathrm{ppm}-2.99 \mathrm{ppm}$ and high range of $5.85 \mathrm{ppm}-9.07$ ppm. So, the total range is $1.93 \mathrm{ppm}-9.07 \mathrm{ppm}$. This result represents that from May to October, phytoplankton growth every day absorbed the low range of atmosphere carbon: $1.93 \mathrm{ppm}-2.99 \mathrm{ppm}$ and high range: 5.85 ppm - 9.07 ppm. Therefore, no matter what low range or high, phytoplankton plays an important role in absorbing atmosphere carbon from time to time.

\subsection{Balance Amount of Primary Production and Atmospheric Carbon}

In one year, primary production and atmosphere carbon have two balance points: two points of May and October. Between two ones, the balance amount of primary production between primary production and atmosphere carbon is $108031.95\left(\mathrm{mg} / \mathrm{m}^{2}\right)$ - $167707.62\left(\mathrm{mg} / \mathrm{m}^{2}\right)$, The balance amount of atmosphere carbon between them is $346.78 \mathrm{ppm}$ - $1633.47 \mathrm{ppm}$. From May to October, the atmosphere carbon decreases by $347-341.41=5.59 \mathrm{ppm}$ or $347-341.42=5.58 \mathrm{ppm}$, which unveils that the carbon discharged by human into atmosphere should be 346.78 ppm - $5.58 \mathrm{ppm} \sim 1633.47 \mathrm{ppm}$ - 5.58 ppm, namely $341.20 \mathrm{ppm}-1627.89 \mathrm{ppm}$ or $346.78 \mathrm{ppm}-5.59 \mathrm{ppm} \sim$ 1633.47 ppm - 5.59 ppm, namely 341.19 ppm - 1627.88 ppm.

From every May to October every year, human discharged 341.20 - 1627.89 ppm or 341.19 - 1627.88 ppm. Therefore, the earth ecosystem every year not only eliminates the carbon emitted by humans into atmosphere and but also reduces the carbon in atmosphere by $5.59 \mathrm{ppm}$ or $5.58 \mathrm{ppm}$, and the falling amount of atmospheric carbon in proportion to the absorption amount of phytoplankton for atmospheric carbon is $0.0160-0.0034$, or $1.60 \%-0.34 \%$. The earth ecosystem every year could keep the atmospheric carbon falling $1.60 \%-0.34 \%$, it is of so great precision.

As humans continuously has been increasing amount of carbon into atmosphere, the earth ecosystem would make the primary production of phytoplankton continuously increase every year in order to reduce atmospheric carbon by $5.59 \mathrm{ppm}$ or $5.58 \mathrm{ppm}$ from May to October. In this way, the earth ecosystem would settle the large amount of carbon in atmosphere to bottom of the sea by phytoplankton to eliminate the carbon discharged by human beings to keep the dynamic balance of carbon emission and absorption of phytoplankton to atmosphere carbon. Therefore, the earth ecosystem is of so great power.

In recent years, phytoplankton has been blooming, result in the global red tides increasing, their frequency, strength, area and scale rapidly enlarging [16,18,20], which strengthen that the earth ecosystem controls atmospheric carbon from May to October to adapt to the increase amount of atmospheric carbon. On the basis of the three complementary mechanism: the complementary mechanism of silicon in the Earth's ecosystem, the complementary mechanism of air temperature and water 
temperature in the Earth's ecosystem, the complementary mechanism of carbon in the Earth's ecosystem by Yang, et al. $[16,18,21]$, air temperature and water temperature reaches the dynamic balance by phytoplankton.

\section{Conclusions}

Atmosphere carbon has obvious season change and one spring peak and one fall bottom. While the primary production has seasonal change with a summer peak and a winter bottom. Atmosphere carbon and primary production has the same seasonal change period. In one year, primary production and atmosphere carbon have two balance points: the balance points of May and October. Atmosphere carbon changes from balance point of May to that of October. During this period, atmosphere carbon all along keeps falling. The atmosphere carbon began to fall at the one balance point of May till it finished at the other balance point of October. As phytoplankton absorbs atmosphere carbon, primary production exceeds $181.60\left(\mathrm{mg} / \mathrm{m}^{2} \mathrm{~d}\right)-297.57\left(\mathrm{mg} / \mathrm{m}^{2} \mathrm{~d}\right)$ in spring and $754.74\left(\mathrm{mg} / \mathrm{m}^{2} \mathrm{~d}\right)-1160.13\left(\mathrm{mg} / \mathrm{m}^{2} \mathrm{~d}\right)$ in September or $552.94\left(\mathrm{mg} / \mathrm{m}^{2} \mathrm{~d}\right)-890.69\left(\mathrm{mg} / \mathrm{m}^{2} \mathrm{~d}\right)$ in October. the atmosphere carbon all the time falls from May to October. Therefore, it is considered that phytoplankton growth in bloom might control the rise of atmosphere carbon.

From May to October, the average primary production is $600.18\left(\mathrm{mg} / \mathrm{m}^{2} \mathrm{~d}\right)-931.71\left(\mathrm{mg} / \mathrm{m}^{2} \mathrm{~d}\right)$, the average carbon of whose absorption is 1.93 ppm - 9.07 ppm. So, blooming phytoplankton growth all the time controls the rise of atmospheric carbon. From May to October, the balance amount of primary production between primary production and atmosphere carbon has its range $108031.95\left(\mathrm{mg} / \mathrm{m}^{2}\right)$ - $167707.62\left(\mathrm{mg} / \mathrm{m}^{2}\right)$, the balance amount of atmospheric carbon between them has its range $346.78 \mathrm{ppm}$ - 1633.47 ppm. So, phytoplankton plays an important role in absorbing atmosphere carbon. Every year from May to October, the carbon discharged by humans into atmosphere should reach $341.20 \mathrm{ppm}$ 1627.89 ppm or 341.19 ppm - 1627.88 ppm. Moreover, the earth ecosystem every year not only eliminates the carbon emitted by humans into atmosphere and but also reduces the carbon in atmosphere by $5.59 \mathrm{ppm}$ or 5.58 ppm, and the falling amount of atmospheric carbon in proportion to the absorption amount of phytoplankton for atmospheric carbon is $0.0160-0.0034$, or $1.60 \%-0.34 \%$, it is of so great precision.

As humans continuously has been increasing amount of carbon into atmosphere, the earth ecosystem would make the primary production of phytoplankton continuously increase every year in order to reduce atmospheric carbon by 5.59 ppm or 5.58 ppm from May to October. In this way, the earth ecosystem would keep the dynamic balance of carbon emission and absorption of phytoplankton to atmosphere carbon. Therefore, the earth ecosystem is of so great power.

The results showed that from May to October phytoplankton growth blooming controls the rise of atmosphere carbon, and phytoplankton could make the atmospheric carbon fall in spite of humans' emission; in other months in every year phytoplankton growth declining could not control the rise of atmosphere carbon, so under the humans' emission the atmosphere carbon increases. Therefore, the bloom and decline period of phytoplankton growth determines the cycle and amplitude of atmospheric carbon variation.

By virtue of the results above, author considered that every year from May to October the phytoplankton growth blooming controls the atmospheric carbon, while from November to next April, the human's emission controls the atmosphere carbon increase, which further supported the viewpoint [9]: both the increase of carbon and its cyclic variation, respectively determined by human discharge and phytoplankton growth, synthetically and harmoniously showed a dynamic process of the atmospheric carbon variation.

Authors considered that the earth ecosystem would not only keep $1.60 \%-0.34 \%$ of the falling amount of atmospheric carbon in proportion to the absorption amount of phytoplankton for atmospheric carbon and but also maintain the dynamic balance of the carbon of humans emission into atmosphere and the phytoplankton absorption to atmosphere carbon. Therefore, the earth ecosystem is certain of so great accuracy and power.

Authors deeply exclaimed that the earth is so perfect, while I am so tiny!

\section{Acknowledgements}

Thanks Prof. Pieter Tans at NOAA Earth System Research Laboratory, NOAA Earth System Research Laboratory and Mauna Loa Observatory, Hawaii for warm help and large support.

\section{References}

[1] D. F. Yang, J. Zhang, J. B. Lu, Z. H. Gao and Y. Chen, "Examination of Silicate Limitation of Primary Production in the Jiaozhou Bay, North China I. Silicate Being a Limiting Factor of Phytoplankton Primary Production," Chinese Journal of Oceanology and Limnology, Vol. 20, No. 3, 2002, pp. 208-225.

[2] D. F. Yang, J. Zhang, Z. H. Gao, Y. Chen and P. Y. Sun, "Examination of Silicate Limitation of Primary Production in the Jiaozhou Bay, North China II. Critical Value and Time of Silicate Limitation and Satisfaction of the Phytoplankton Growth," Chinese Journal of Oceanology and Limnology, Vol. 21, No. 1, 2003a, pp. 46-63. 
[3] D. F. Yang, Z. H. Gao, Y. Chen, J. Zhang and P. G. Wang, "Examination of Silicate Limitation of Primary Production in the Jiaozhou Bay, North China III: Judgment Method, Rules and Uniqueness of Nutrient Limitation among N, P and Si," Chinese Journal of Oceanology and Limnology, Vol. 21, No. 2, 2003b, pp. 114-133.

[4] D. F. Yang, Z. H. Gao, P. Y. Sun, Q. L. Li and L. J. Chen, "The Studies of Phytoplankton Reproduction Capacity," Marine Sciences, Vol. 27, No. 5, 2003c, pp. 26-28.

[5] D. F. Yang, Z. H. Gao, Y. Chen, P. G. Wang and P. Y. Sun, "Examination of Seawater Temperature's Influence on Phytoplankton Growth in Jiaozhou Bay, North China," Chinese Journal of Oceanology and Limnology, Vol. 22, No. 2, 2004a, pp. 166-175. doi:10.1007/BF02842589

[6] D. F. Yang, Z. H. Gao, P. Y. Sun, B. Zhao and M. Li, "Spatial and Temporal Variation of the Primary Production Limited by Nutrient Silicon and Water Temperature in Jiaozhou Bay," Advances in Marine Science, Vol. 24, No. 2, 2006a, pp. 203-212.

[7] D. F. Yang, Z. H. Gao, P. G. Wang, Z. J. Yu and Q. Shi, "Mechanism of Nutrient Silicon and Water Temperature' Influence on Phytoplankton," Marine Environmental Science, Vol. 25, No. 1, 2006b, pp. 1-6.

[8] D. F. Yang, Z. H. Gao, P. Y. Sun, S. Zhao and Y. C. Zhang, "Silicon Limitation on Primary Production and Its Destiny in Jiaozhou Bay, China VI: The Ecological Variation Process of the phytoplankton," Chinese Journal of Oceanology and Limnology, Vol. 24, No. 2, 2006c, pp. 186-203.

[9] D. F. Yang, Z. Q. Miao, Q. Shi, Y. Chen and G. G. Chen, "Silicon Limitation on Primary Production and Its Destiny in Jiaozhou Bay, China VIII: The Variation of Atmospheric Carbon Determined by Both Phytoplankton and Human," Chinese Journal of Oceanology and Limnology, Vol. 28, No. 2, 2010, pp. 416-425. doi:10.1007/s00343-010-9132-0

[10] K. W. Thoning, P. P. Tans and W. D. Komhyr, "Atmospheric Carbon Dioxide at Mauna Loa Observatory: 2. Analysis of the NOAA GMCC Data, 1974-1985," Journal of Geophysical Research, Vol. 24, No. D6, 1989, pp. 8549-8565. doi:10.1029/JD094iD06p08549

[11] W. D. Komhyr, T. B. Harris and L. S. Waterman, "Atmospheric Carbon Dioxide at Mauna Loa Observatory: 1. NOAA GMCC Measurements with a Non-Dispersive Infrared Analyzer," Journal of Geophysical Research, Vol. 94, No. D6, 1989, pp. 8533-8547.

\section{doi:10.1029/JD094iD06p08533}

[12] C. D. Keeling, T. P. Whorf and M. Wahlen, "Interannual Extremes in the Rate of Rise of Atmospheric Carbon Dioxide since 1980," Nature, Vol. 375, 1995, pp. 666-670. doi:10.1038/375666a0

[13] C. D. Keeling, J. F. S. Chin and T. P. Whorf, 'Increased Activity of Northern Vegetation Inferred from Atmospheric $\mathrm{CO}_{2}$ Measurements," Nature, Vol. 382, No. 6587, 1996, pp. 146-149. doi:10.1038/382146a0

[14] Y. L. Wu and Y. S. Zhang, "Chlorophyll-a of Jiaozhou Bay and Characteristic Distribution of Primary Productivity," In: J. H. Dong and N. Z. Jiao eds., Ecology Resources of Jiaozhou Bay, Science Press, Beijing, 1995, pp. 137-149.

[15] D. F. Yang, Z. H. Gao, J. Qin, S. X. Huo and Z. Q. Li, "The Complementary Mechanism of Nutrient Silicon in the Earth Ecosystem," Advance in Marine Science, Vol. 24, No. 4, 2006d, pp. 407-412.

[16] D. F. Yang, J. P. Wu, Y. F. Qu, J. Hu and Y. R. Zhou, "The Complementary Mechanism of Air and Water Temperatures in the Earth Ecosystem," Advance in Marine Science, Vol. 25, No. 1, 2007a, pp. 117-122.

[17] D. F. Yang, S. T. Chen, J. Hu, J. P. Wu and H. Huang, "The Important Effect of Light, Water Temperature and Nutrients on Phytoplankton Growth," Marine Environmental Science, Vol. 26, No. 3, 2007b, pp. 201-207.

[18] D. F. Yang, Y. F. Yin, J. Y. Sun, W. H. Jin and F. Gao, "The Complementary Mechanism of Carbon in the Earth Ecosystem," Marine Environmental Science, Vol. 28, No. 3, 2009, pp. 101-107.

[19] D. F. Yang, F. Wang, Z. H. Gao, W. L. Cui and S. X. Huo, "Ecological Phenomena of Phytoplankton in Jiaozhou Bay," Marine Sciences, Vol. 28, No. 6, 2004b, pp. 71-74.

[20] D. F. Yang, Z. J. Yu, K. Zhang, M. Li and D. Y. Jiang, "The Limitation of Nutrient Si Limited for Phytoplankton Growth in the Global Marine Area," Advances in Marine Science, Vol. 27, No. 5, 2008, pp. 547-553.

[21] D. F. Yang, Z. H. Gao, Y. B. YANG, P. Y. Sun and X. P. Wang, "Silicon Limitation on Primary Production and Its Destiny in Jiaozhou Bay, ChinaVII The Complementary Mechanism of the Earth Ecosystem," Chinese Journal of Oceanology and Limnology, Vol. 24, No. 4, 2006e, pp. 401-412. doi:10.1007/BF02842857 